\title{
Nitrogen fertilization and glyphosate doses as growth regulators in Esmeralda grass
}

\author{
Raíssa P. D. Gazola ${ }^{1}$, Salatiér Buzetti², Rodolfo de N. Gazola², Regina M. M. de Castilho ${ }^{1}$, \\ Marcelo C. M. Teixeira Filho² \& Thiago de S. Celestrino ${ }^{2}$
} ${ }^{1}$ Universidade Estadual Paulista/Faculdade de Engenharia/Departamento de Fitotecnia, Tecnologia de Alimentos e Sócio Economia. Ilha Solteira, SP,
Brasil. E-mail: raissadinalli@gmail.com - ORCID: 0000-0002-3207-6291; castilho.re50@gmail.com - ORCID: 0000-0003-3421-7235
${ }^{2}$ Universidade Estadual Paulista/Faculdade de Engenharia/Departamento de Fitossanidade, Engenharia Rural e Solos. Ilha Solteira, SP, Brasil. E-mail:
sbuzetti@agr.feis.unesp.br - ORCID: 0000-0003-2569-4750; rngazola@gmail.com - ORCID: 0000-0003-0640-5175; mcmt@@yahoo.com.br (Corresponding
author) - ORCID: 0000-0003-2303-3465; thiagocelestrino@yahoo.com.br - ORCID: 0000-0002-8380-237X

\begin{abstract}
Despite maintaining the green color in turfgrasses, nitrogen $(\mathrm{N})$ fertilization affects shoot growth and, consequently, the frequency of cuts, the main factor in the costs of turfgrass maintenance. Therefore, this study aimed to evaluate $\mathrm{N}$ fertilization and the use of glyphosate as a growth regulator in Esmeralda grass (Zoysia japonica Steud.). The experiment was conducted in the field, from August 2014 to July 2015, using a randomized block design in a $5 \times 4$ factorial scheme with four repetitions and 20 treatments, namely: control (without N), $15 \mathrm{~g} \mathrm{~m}^{-2}$ of $\mathrm{N}$ in soil without foliar $\mathrm{N} ; 30 \mathrm{~g} \mathrm{~m}^{-2}$ of $\mathrm{N}$ in soil without foliar $\mathrm{N} ; 15 \mathrm{~g} \mathrm{~m}^{-2}$ of $\mathrm{N}$ in soil with foliar $\mathrm{N}$ ( $1 \%$ urea in $200 \mathrm{~L} \mathrm{ha}^{-1}$ ) and $30 \mathrm{~g} \mathrm{~m}^{-2}$ of $\mathrm{N}$ in soil with foliar $\mathrm{N}$ combined with glyphosate doses $\left(0,200,400\right.$ and $600 \mathrm{~g} \mathrm{ha}^{-1}$ active ingredient (a.i.)). The $\mathrm{N}$ doses were split into five applications along the year. The following variables were evaluated: height, leaf chlorophyll index and foliar accumulation of nitrogen, phosphorus and potassium. Fertilization with $15 \mathrm{~g} \mathrm{~m}^{-2}$ of $\mathrm{N}$ in soil without foliar $\mathrm{N}$ application, split into five times along the year, was adequate for the turfgrass, while foliar fertilization did not promote benefits. The glyphosate dose of $400 \mathrm{~g} \mathrm{ha}^{-1}$ a.i. was effective in reducing the growth of Esmeralda grass, without compromising its color and promoted less $\mathrm{N}, \mathrm{P}$ and $\mathrm{K}$ accumulation in the leaves, reducing the height and dry matter production.
\end{abstract}

Key words: Zoysia japonica Steud, nutrient removal, nutrition

\section{Adubação nitrogenada e doses do herbicida glifosato como regulador de crescimento em grama esmeralda}

RESUMO: Apesar de manter a coloração verde em gramados, a adubação nitrogenada influencia o crescimento da parte aérea e, assim, a frequência de cortes, principal custo de manutenção em gramados. Portanto, objetivou-se avaliar a adubação nitrogenada e o uso do glifosato como regulador de crescimento em grama esmeralda (Zoysia japonica Steud.). O experimento foi conduzido em campo, de agosto/2014 a julho/2015, usando o delineamento em blocos casualizados com 20 tratamentos dispostos em esquema fatorial $5 \times 4$, com quatro repetições, sendo a testemunha (sem nitrogênio - $\mathrm{N}$ ); $15 \mathrm{~g} \mathrm{~m}^{-2} \mathrm{de} \mathrm{N}$ via solo e sem $\mathrm{N}$ via foliar; $30 \mathrm{~g} \mathrm{~m}^{-2}$ de $\mathrm{N}$ via solo e sem $\mathrm{N}$ via foliar; $15 \mathrm{~g} \mathrm{~m}^{-2}$ de $\mathrm{N}$ via solo e com $\mathrm{N}$ via foliar ( $1 \%$ de ureia em calda de $\left.200 \mathrm{~L} \mathrm{ha}^{-1}\right)$; e $30 \mathrm{~g} \mathrm{~m}^{-2}$ de $\mathrm{N}$ via solo e com $\mathrm{N}$ via foliar combinados com doses de glifosato $\left(0,200,400\right.$ e $600 \mathrm{~g} \mathrm{ha}^{-1}$ do ingrediente ativo - i.a.). As doses de $\mathrm{N}$ foram parceladas em cinco aplicações ao ano. Avaliaram-se: altura, índice de clorofila foliar e acúmulo nas folhas de nitrogênio, fósforo e potássio. A adubação com $15 \mathrm{~g} \mathrm{~m}^{-2} \mathrm{de}$ $\mathrm{N}$ via solo e sem $\mathrm{N}$ via foliar, parcelada em cinco aplicações ao ano, foi adequada ao gramado, enquanto a adubação foliar não apresentou benefícios ao gramado. O glifosato na dose de $400 \mathrm{~g} \mathrm{ha}^{-1}$ do i.a. foi eficiente na redução do crescimento da grama esmeralda, sem prejuízo na sua coloração verde e também propiciou menor acúmulo de N, P e K foliares, reduzindo altura e produção de matéria seca.

Palavras-chave: Zoysia japonica Steud, exportação de nutrientes, nutrição 


\section{INTRODUCTION}

Esmeralda grass is used in most of the Brazilian residential gardens (Godoy et al., 2012a), but there are still few studies on planted lawns (Dinalli et al., 2015), and fertilizer recommendations are subjective.

The application of higher nitrogen $(\mathrm{N})$ doses leads to a more intense green color in the lawns (Dinalli et al., 2015; Gazola et al., 2016). However, there is higher dry matter production and extraction of nutrients in Esmeralda (Backes et al., 2010) and Bermuda grass (Cynodon dactylon) (Lima et al., 2015), as well as N in St. Augustine grass (Stenotaphrum secundatum Kuntze) (Godoy et al., 2012b). This increases the cost of lawn maintenance (Backes et al., 2010; Godoy et al., 2012a), since more cuts will be needed, in addition to the replenishment of nutrients through fertilization.

Therefore, there is a need for alternatives for management, such as the use of plant growth regulators (March et al., 2013), and the ideal is the one which reduces height and dry matter production (lower nutrient export), without causing visible damage to the plants (Christoffoleti \& Aranda, 2001; March et al., 2013).

Glyphosate as a growth regulator promoted lower height of rice plants (Gitti et al., 2011), lower growth of sugarcane (Leite \& Crusciol, 2008; Silva et al., 2009; Meschede et al., 2010) and lower dry matter production in Paspalum notatum (Barbosa et al., 2017); however, in lawns, doses above a certain limit can cause damage and even death (Kaufmann, 1985).

Dinalli et al. (2015) concluded that $200 \mathrm{~g} \mathrm{ha}^{-1}$ of the a.i. of glyphosate stood out in controlling the growth of Esmeralda grass, did not compromise its aesthetic quality, and can be used as a growth regulator.
In this context, the objective of present study was to evaluate $\mathrm{N}$ fertilization and the use of glyphosate doses as growth regulator in Esmeralda grass aiming to maintain the visual quality and evaluate the leaf accumulation of $\mathrm{N}, \mathrm{P}$ and $\mathrm{K}$ by the lawn.

\section{Material ANd Methods}

The experiment was conducted from August 2014 to July 2015, at the Farm of Teaching, Research and Extension of the Faculdade de Engenharia of the Universidade Estadual Paulista, at $20^{\circ} 22^{\prime} 23.5^{\prime \prime} \mathrm{S}, 51^{\circ} 22^{\prime} 12.6^{\prime \prime} \mathrm{W}$ and $330 \mathrm{~m}$ of altitude, in Ilha Solteira, SP, Brazil, in a sandy clay Ultisol, in lawn planted by carpets $(0.63 \times 0.40 \mathrm{~m})$, on August 3, 2012, and irrigated by sprinklers during the experimental period. Irrigation management was performed according to crop evapotranspiration and the Penman-Monteith method, using the kc of 0.94 (Silva, 2004).

Monthly averages of precipitation and minimum and maximum temperatures, which encompassed the experimental period, were obtained by the meteorological station of Ilha Solteira, through the CLIMA channel of UNESP Ilha Solteira Hydraulics and Irrigation Sector, and are presented in Figure 1.

On August 8, 2014, soil chemical analysis was performed at $0-0.20 \mathrm{~m}$ layer, according to the methodology described by Raij et al. (2001), and its results were: $30 \mathrm{mg} \mathrm{dm}^{-3}$ of $\mathrm{P}$ (resin); $17 \mathrm{~g} \mathrm{dm}^{-3}$ of OM; 6.4 of $\mathrm{pH}\left(\mathrm{CaCl}_{2}\right) ; \mathrm{K}, \mathrm{Ca}, \mathrm{Mg}, \mathrm{H}+\mathrm{Al}$ $=0.7,25.0,16.0$ and $11.0 \mathrm{mmol}_{\mathrm{c}} \mathrm{dm}^{-3}$, respectively and $\mathrm{V} \%$ of 79. Potassium fertilization was carried out using potassium chloride $\left(60 \% \mathrm{~K}_{2} \mathrm{O}\right)$ at dose of $10 \mathrm{~g} \mathrm{~m}^{-2}$ year-1 of $\mathrm{K}_{2} \mathrm{O}$, split into five times, on the same days of $\mathrm{N}$ fertilization via soil.

The treatments began to be applied in October/2014, using a randomized block design with 20 treatments arranged in

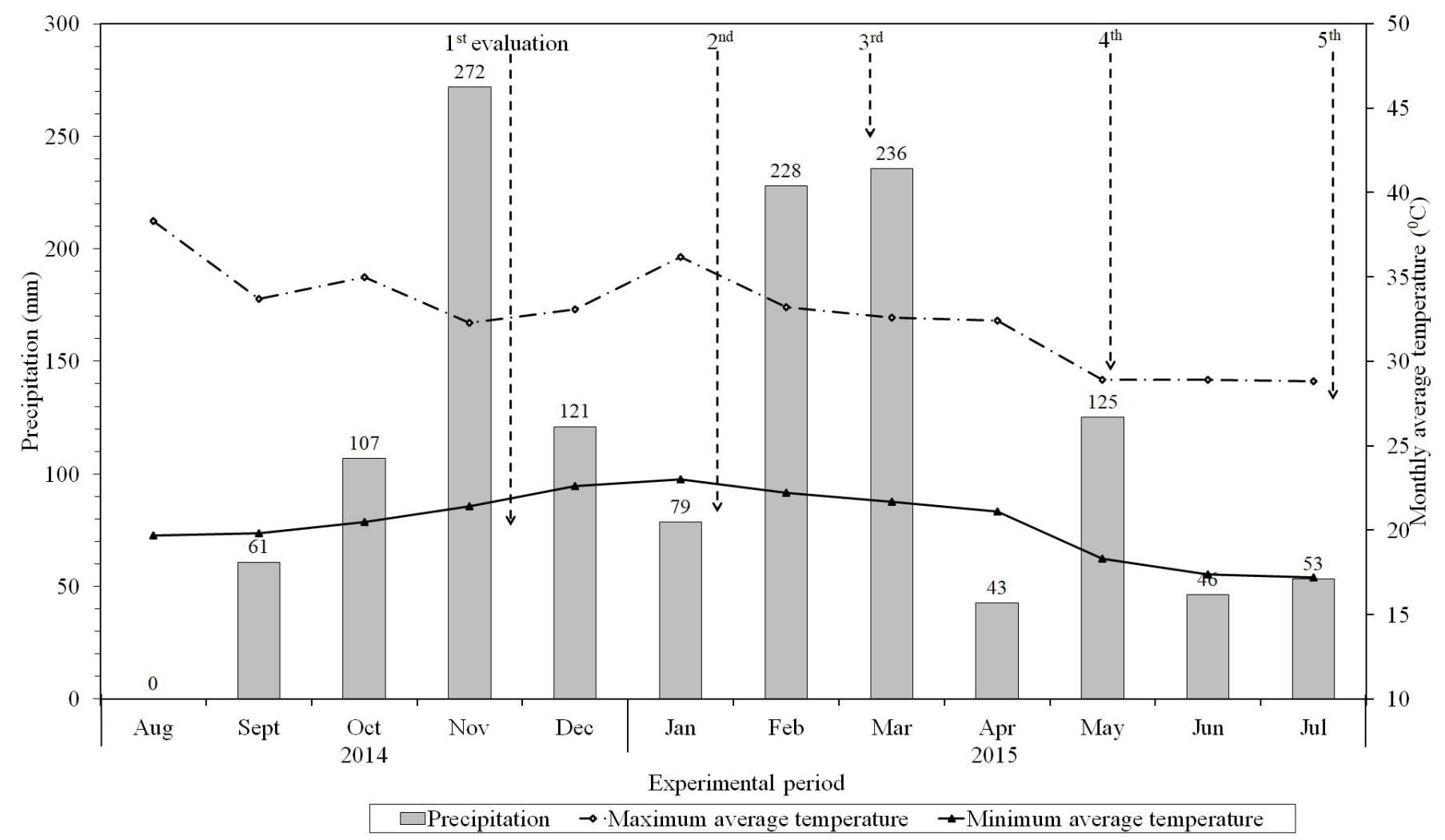

Figure 1. Monthly averages of precipitation and minimum and maximum mean temperatures along the experimental period 
a $5 \mathrm{x} 4$ factorial scheme with four repetitions, $10 \mathrm{~m}^{2}$ per plot. The treatments were: control (without $\mathrm{N}$ ); $15 \mathrm{~g} \mathrm{~m}^{-2}$ of $\mathrm{N}$ via soil and without foliar $\mathrm{N}$ application; $30 \mathrm{~g} \mathrm{~m}^{-2}$ of $\mathrm{N}$ via soil and without foliar $\mathrm{N}$ application; $15 \mathrm{~g} \mathrm{~m}^{-2}$ of $\mathrm{N}$ via soil and with foliar $\mathrm{N}$ application (1\% urea in $200 \mathrm{~L} \mathrm{ha}^{-1}$ ) and $30 \mathrm{~g} \mathrm{~m}^{-2}$ of $\mathrm{N}$ via soil and with foliar $\mathrm{N}$ application (1\% urea in $200 \mathrm{~L} \mathrm{ha}^{-1}$ ) combined with four doses of glyphosate $(0,200,400$ and $600 \mathrm{~g} \mathrm{ha}^{-1}$ of a.i.).

The $\mathrm{N}$ source used was urea $(45 \% \mathrm{~N})$, applied manually via soil, immediately after cutting the lawn, on: $16 / 10$ and $09 / 12$ of $2014,29 / 01,18 / 03$ and $23 / 05$ of 2015 , respectively, for the $1^{\text {st }}, 2^{\text {nd }}, 3^{\text {rd }}, 4^{\text {th }}$ and $5^{\text {th }}$ evaluations. The $\mathrm{N}$ doses via soil were split into five applications along the year, corresponding to 3 and $6 \mathrm{~g} \mathrm{~m}^{-2}$ of $\mathrm{N}$ in each application, respectively, for the doses of 15 and $30 \mathrm{~g} \mathrm{~m}^{-2}$ of $\mathrm{N}$. After each fertilization, the lawn was irrigated with a water depth of approximately $14 \mathrm{~mm}$, aiming to reduce losses of $\mathrm{NH}_{3}-\mathrm{N}$ by volatilization.

Herbicide application, carried out on the days $31 / 10$ and $24 / 12$ of 2014 , and $12 / 02,17 / 04$ and $23 / 06$ of 2015 , for the $1^{\text {st }}$, $2^{\text {nd }}, 3^{\text {rd }}, 4^{\text {th }}$ and $5^{\text {th }}$ evaluations, respectively, which occurred in the morning, under mild temperature conditions, using a $\mathrm{CO}_{2}$-pressurized backpack sprayer with a 2-L tank (disposable PET bottles), bar with 4 anti-drip tips spaced by $0.50 \mathrm{~m}$, model 80.02 , mix consumption equivalent to $200 \mathrm{~L} \mathrm{ha}^{-1}$ and operating pressure of 3 psi. The application was performed at 15 or 30 days after $\mathrm{N}$ fertilizations applied via soil, and the first interval corresponded to the spring/summer months $\left(1^{\text {st }}, 2^{\text {nd }}\right.$ and $3^{\text {rd }}$ evaluations) while the second corresponded to the autumn/ winter months ( $4^{\text {th }}$ and $5^{\text {th }}$ evaluations). This is because, under Brazilian conditions, grass growth in autumn/winter is not as intense as in spring/summer.

Foliar $\mathrm{N}$ application was performed using $1 \%$ urea in solution of $200 \mathrm{~L} \mathrm{ha}^{-1}$, referring to $0.09 \mathrm{~g} \mathrm{~m}^{-2}$ of $\mathrm{N}$. It was carried out in the morning, under mild temperature conditions, with the same sprayer used for herbicide application. These applications occurred 7 days after application (DAA) of the herbicide, in order to verify its effect on the green color of the lawn, on $07 / 11$ and $31 / 12$ of $2014,19 / 02,24 / 04$ and $30 / 06$ of 2015, referring to the $1^{\text {st }}, 2^{\text {nd }}, 3^{\text {rd }}, 4^{\text {th }}$ and $5^{\text {th }}$ evaluations, respectively.

Five evaluations were performed, $30 \mathrm{DAA}$ of the herbicides, on: $30 / 11 / 2014\left(1^{\text {st }}\right), 24 / 01 / 2015\left(2^{\text {nd }}\right), 12 / 03 / 2015\left(3^{\text {rd }}\right)$, $17 / 05 / 2015\left(4^{\text {th }}\right)$ and $23 / 07 / 2015\left(5^{\text {th }}\right)$. After the collection of plant material, cuttings were made on the lawn using a gasoline-fueled mower with a clipping collector to standardize the size of the Esmeralda grass in the treatments, always keeping the height close to $3 \mathrm{~cm}$ from soil level.

The following parameters were evaluated: a) lawn height: using a prism gauge (portable device made of steel and glass (mirror) which reflects the light at $90^{\circ}$ angle and contains a scale graduated in $\mathrm{cm}$ ), which was placed on the surface of the lawn, at three points, obtaining a mean value; b) Leaf Chlorophyll Index (LCI): the measurements were performed in the laboratory, due to the reduced size of grass leaves and the difficulty of handling, using a portable hand-held chlorophyll meter (Falker - CFL 1030), evaluating 15 leaves per plot, which were manually collected in the morning, placed in identified paper bags and stored in polystyrene box containing ice so that they did not curl (which would compromise the reading), performing one measurement per leaf in the middle of the leaf blade; and c) accumulation of N, P and K by the leaves: calculated by multiplying the values of dry matter per square meter and the concentration of these nutrients in the leaves and determined according to the methodology adapted from Malavolta et al. (1997), which was carried out in order to verify the export of these nutrients due to the removal of clippings after cutting the grass. As the accumulations of the five evaluations were considered, $\mathrm{N}$ fertilization was mentioned as such, i.e., 15 and $30 \mathrm{~g} \mathrm{~m}^{-2}$ of $\mathrm{N}$, corresponding to 3 and $6 \mathrm{~g}$ $\mathrm{m}^{-2}$ of $\mathrm{N}$, respectively, in five applications/evaluations.

The data were subjected to analysis of variance and Tukey test at $\mathrm{p} \leq 0.05$ to compare the means of $\mathrm{N}$ applications via soil and leaves, and polynomial regression models were fitted for glyphosate doses, using the program Sisvar (Ferreira, 2011) for statistical analysis.

\section{Results AND Discussion}

In the $1^{\text {st }}, 2^{\text {nd }}$ and $5^{\text {th }}$ evaluations, the highest values of Esmeralda grass height were obtained with the application of $6 \mathrm{~g} \mathrm{~m}^{-2}$ of $\mathrm{N}$ via soil and with foliar $\mathrm{N}$ application, which did not differ from $6 \mathrm{~g} \mathrm{~m}^{-2}$ of $\mathrm{N}$ via soil and without foliar $\mathrm{N}$ application. It also did not differ from $3 \mathrm{~g} \mathrm{~m}^{-2}$ of $\mathrm{N}$ via soil and with foliar $\mathrm{N}$ application, in the $2^{\text {nd }}$ and in the $5^{\text {th }}$ evaluations. The lowest values of grass height were observed in the control. In the $4^{\text {th }}$ evaluation, all treatments promoted higher grass heights compared to the control (lowest value) (Table 1).

Table 1. Height of Esmeralda grass, in five evaluations, as a function of nitrogen fertilization and glyphosate doses

\begin{tabular}{|c|c|c|c|c|c|}
\hline \multirow{2}{*}{ Nitrogen fertilization } & \multicolumn{5}{|c|}{ Height (cm) } \\
\hline & $1^{\text {st }}$ & $2^{\text {nd }}$ & $3^{\text {rd }}$ & $4^{\text {th }}$ & $5^{\mathrm{th}}$ \\
\hline Control & $3.8 \mathrm{c}$ & $3.6 \mathrm{c}$ & 3.6 & $3.1 \mathrm{~b}$ & $3.1 \mathrm{c}$ \\
\hline $3 \mathrm{~g} \mathrm{~m}^{-2}$ of $\mathrm{N}$ and without foliar $\mathrm{N}$ & $4.6 \mathrm{~b}$ & $4.2 \mathrm{bc}$ & 3.8 & $4.0 \mathrm{a}$ & $4.2 b$ \\
\hline $3 \mathrm{~g} \mathrm{~m}^{-2}$ of $\mathrm{N}$ and with foliar $\mathrm{N}$ & $4.8 \mathrm{~b}$ & $4.3 a b$ & 4.0 & $3.9 \mathrm{a}$ & $4.5 \mathrm{ab}$ \\
\hline $6 \mathrm{~g} \mathrm{~m}^{-2}$ of $\mathrm{N}$ and without foliar $\mathrm{N}$ & $4.9 a b$ & $4.4 a b$ & 4.4 & $4.5 \mathrm{a}$ & $4.8 \mathrm{a}$ \\
\hline $6 \mathrm{~g} \mathrm{~m}^{-2}$ of $\mathrm{N}$ and with foliar $\mathrm{N}$ & $5.5 \mathrm{a}$ & $4.8 \mathrm{a}$ & 4.4 & $4.0 \mathrm{a}$ & $4.8 \mathrm{a}$ \\
\hline LSD (5\%) & 0.6 & 0.6 & 0.3 & 0.6 & 0.5 \\
\hline \multicolumn{6}{|l|}{ Ghyphosate doses (g ha-1 of a.i.) } \\
\hline 0 & $5.1^{(1)}$ & $4.6^{(2)}$ & 4.9 & $3.9^{\text {ns }}$ & $4.6^{(3)}$ \\
\hline 200 & 4.9 & 4.4 & 4.1 & 4.1 & 4.3 \\
\hline 400 & 4.6 & 4.2 & 3.7 & 3.8 & 4.0 \\
\hline 600 & 4.3 & 3.8 & 3.4 & 3.8 & 4.1 \\
\hline C.V. (\%) & 12.50 & 14.64 & 8.60 & 16.37 & 11.62 \\
\hline $\mathrm{F}_{\mathrm{N} \text { fertilizationx Ghyphosate doses }}$ & $1.36^{\text {ns }}$ & $1.11^{\text {ns }}$ & $4.36^{* \star}$ & $1.12^{\text {ns }}$ & $1.56^{\text {ns }}$ \\
\hline
\end{tabular}


However, such increase in leaf growth promoted by higher $\mathrm{N}$ doses is not desirable from an economic point of view, since it increases the number of cuts and, therefore, the extraction (export) of nutrients and lawn maintenance costs (Backes et al., 2010; Godoy et al., 2012a).

When 3 and $6 \mathrm{~g} \mathrm{~m}^{-2}$ of $\mathrm{N}$ were applied via soil, there was no difference in lawn height, compared to the addition or not of foliar $\mathrm{N}$ application (Table 1). This occurs because the foliar $\mathrm{N}$ application dose was low $\left(0.09 \mathrm{~g} \mathrm{~m}^{-2}\right)$ in comparison to those applied via soil ( 3 and $6 \mathrm{~g} \mathrm{~m}^{-2}$ of $\mathrm{N}$ ), not influencing the growth of the lawn. The main objective of foliar application of $\mathrm{N}$ was to verify its effect on the green color of the lawn.

Dinalli et al. (2015) observed higher growth of Esmeralda grass fertilized with $\mathrm{N}\left(0,5,10\right.$ and $20 \mathrm{~g} \mathrm{~m}^{-2}$, split into five times a year), in three of the five evaluations performed by the authors. Similarly, Lima et al. (2015), in an experiment with Bermuda grass, noted that the increase in $\mathrm{N}$ doses $(0,15,30$, 45 and $60 \mathrm{~g} \mathrm{~m}^{-2}$, split and applied at 40,89 and 124 days after cutting the previous carpet) promoted greater leaf growth.

There was a decrease in Esmeralda grass height with the increase in glyphosate doses, in the $1^{\text {st }}, 2^{\text {nd }}$ and $5^{\text {th }}$ evaluations (Table 1), with reductions of $16.4,16.8$ and $11.9 \%$ in leaf height, respectively, when applying the highest dose in comparison to no herbicide application. The same has been observed in other studies with the application of this herbicide in lawns, with reduction of $20.5 \%$ in the leaf height of Esmeralda grass with the dose of $200 \mathrm{~g} \mathrm{ha}^{-1}$ of the a.i. (Dinalli et al., 2015), decrease in $22.0 \%$ in the height of Centipede grass with the application of $600 \mathrm{~g} \mathrm{ha}^{-1}$ of a.i. (Fry, 1991) and lower height of Bahia grass with the dose of $246 \mathrm{~g} \mathrm{ha}^{-1}$ of a.i. (Barbosa et al., 2017).

In the third evaluation, there was interaction between $\mathrm{N}$ application and herbicide doses for leaf height (Figure 2). For the control and when $6 \mathrm{~g} \mathrm{~m}^{-2}$ of $\mathrm{N}$ was applied via soil, without

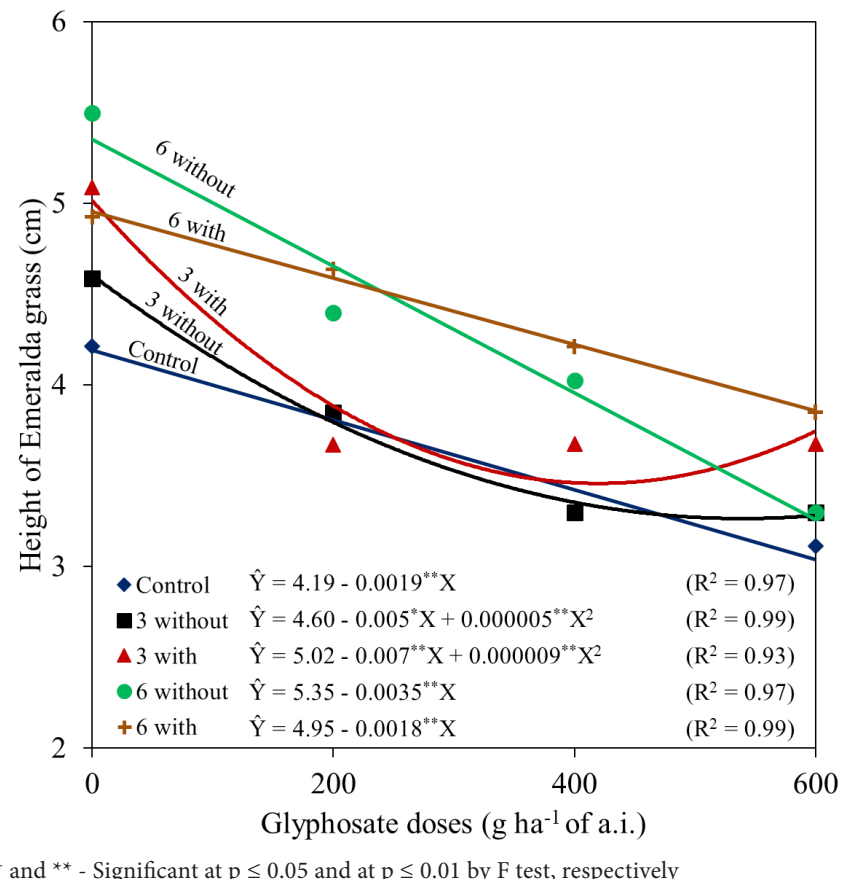

Figure 2. Height of Esmeralda grass, in the third evaluation, obtained from the single-effect analysis of the application of glyphosate doses at each form of $\mathrm{N}$ application and with foliar $\mathrm{N}$ application, there was a linear reduction in grass height with the increase of glyphosate doses, and the values were, respectively, $3.0,3.2$ and $3.9 \mathrm{~cm}$ for the dose of $600 \mathrm{~g} \mathrm{ha}^{-1}$ of the a.i., in comparison to the non-application of the herbicide. When applying $3 \mathrm{~g} \mathrm{~m}^{-2}$ of $\mathrm{N}$ via soil, with and without foliar $\mathrm{N}$ application, there was a quadratic effect and, with $3 \mathrm{~g} \mathrm{~m}^{-2}$ of $\mathrm{N}$ via soil and without foliar $\mathrm{N}$ application, the lowest height was $3.4 \mathrm{~cm}$, with the estimated glyphosate dose of $500 \mathrm{~g} \mathrm{ha}^{-1}$ of the a.i. For the application of $3 \mathrm{~g} \mathrm{~m}^{-2}$ of $\mathrm{N}$ via soil and with foliar $\mathrm{N}$ application, the lowest height was 3.7 $\mathrm{cm}$, with glyphosate dose of $389 \mathrm{~g} \mathrm{ha}^{-1}$ of the a.i.

An inference can be made as to the need for cutting Esmeralda grass based on the study of Johnson (1994), according to which Bermuda grass should be cut when the lawn reached one third of its height, i.e. $33.33 \%$ above the cutting height of $3.0 \mathrm{~cm}(>4.0 \mathrm{~cm})$. Therefore, at these doses of the herbicide, the cut would not be necessary, considering the inference made.

These reductions in growth are due to the mechanism of action of glyphosate, which acts on the route of the shikimic acid, inhibiting the enzyme EPSPs, responsible for the formation of the aromatic amino acid tryptophan, precursor of the biosynthesis of AIA, which depends on this amino acid (Velini et al., 2009). The biosynthesis of tryptophan-independent AIA has as precursor the indole3-glycerol phosphate, which in turn depends on chorismate for its formation. As the synthesis of chorismate is inhibited by glyphosate, the biosynthesis of tryptophan-independent AIA can also be inhibited by the herbicide. In other words, glyphosate completely blocks AIA synthesis.

Another important plant growth promoter is gibberellin, whose biosynthesis is promoted by the AIA (Yamada \& Castro, 2007), besides increasing the synthesis of ethylene, which is growth inhibitor (Meschede et al., 2010). In this context, changes in the route of shikimic acid lead to reduction of plant growth.

Another justification is the increased activity of phenylalanine ammonia lyase (PAL), which reduces free phenylalanine and possibly tyrosine, inhibiting protein synthesis or, also, through the production of toxic levels of ammonia and/or increasing the levels of phenolic compounds that inhibit growth (Duke et al., 1980).

In the $1^{\text {st }}$ and $2^{\text {nd }}$ evaluations, the highest LCI was obtained when the grass was fertilized with $6 \mathrm{~g} \mathrm{~m}^{-2}$ of $\mathrm{N}$ via soil and without foliar $\mathrm{N}$ application, compared to the absence of fertilization (control). In the $3^{\text {rd }}$ and $5^{\text {th }}$ evaluations, all treatments led to higher LCI than that of the control, except in the $3^{\text {rd }}$ evaluation with the application of $3 \mathrm{~g} \mathrm{~m}^{-2}$ of $\mathrm{N}$ via soil and without foliar $\mathrm{N}$ application, whose values did not differ from those of the control (Table 2).

As in this study, Dinalli et al. (2015) found, for Esmeralda grass, higher LCC values with $\mathrm{N}$ fertilization $\left(0,5,10\right.$ and $20 \mathrm{~g} \mathrm{~m}^{-2}$, split into five times a year), in three of the five evaluations performed. The same was verified by Gazola et al. (2016), in four evaluations. It should be pointed out that there are few studies evaluating LCC in planted lawns, without focusing on grass production.

The results obtained for LCI confirmed the influence of $\mathrm{N}$ on the green color of the lawn and emphasized that higher 
Table 2. Leaf Chlorophyll Index (LCI) of Esmeralda grass, in five evaluations, as a function of nitrogen fertilization and glyphosate doses

\begin{tabular}{|c|c|c|c|c|c|}
\hline \multirow{2}{*}{ Nitrogen fertilization } & \multicolumn{5}{|c|}{ LCI } \\
\hline & $1^{\text {st }}$ & $2^{\text {nd }}$ & $3^{\text {rd }}$ & $4^{\text {th }}$ & $5^{\text {th }}$ \\
\hline Control & $21.4 \mathrm{~b}$ & $21.2 \mathrm{~b}$ & $18.9 \mathrm{~b}$ & $21.2 \mathrm{a}$ & $18.9 \mathrm{~b}$ \\
\hline $3 \mathrm{~g} \mathrm{~m}^{-2}$ of $\mathrm{N}$ and without foliar & $23.0 \mathrm{ab}$ & $22.5 \mathrm{ab}$ & $20.7 \mathrm{ab}$ & $24.5 \mathrm{a}$ & $22.9 \mathrm{a}$ \\
\hline $3 \mathrm{~g} \mathrm{~m}^{-2}$ of $\mathrm{N}$ and with foliar & $22.6 \mathrm{ab}$ & $22.1 \mathrm{ab}$ & $23.5 \mathrm{a}$ & $22.8 \mathrm{a}$ & $22.2 \mathrm{a}$ \\
\hline $6 \mathrm{~g} \mathrm{~m}^{-2}$ of $\mathrm{N}$ and without foliar & $24.5 \mathrm{a}$ & $23.6 \mathrm{a}$ & $23.2 \mathrm{a}$ & $24.5 \mathrm{a}$ & $23.1 \mathrm{a}$ \\
\hline $6 \mathrm{~g} \mathrm{~m}^{-2}$ of $\mathrm{N}$ and with foliar & $23.3 \mathrm{ab}$ & $22.4 \mathrm{ab}$ & $22.5 \mathrm{a}$ & $24.2 \mathrm{a}$ & $23.2 \mathrm{a}$ \\
\hline LSD $(5 \%)$ & 1.9 & 1.9 & 3.2 & 3.4 & 2.2 \\
\hline \multicolumn{6}{|l|}{ Glyphosate doses (g ha ${ }^{-1}$ of a.i.) } \\
\hline 0 & $24.5^{(1)}$ & $23.2^{(2)}$ & $20.6^{\text {ns }}$ & $22.9^{\text {ns }}$ & $21.7^{\text {ns }}$ \\
\hline 200 & 23.4 & 22.7 & 21.7 & 23.4 & 22.3 \\
\hline 400 & 22.3 & 21.9 & 23.1 & 23.6 & 22.7 \\
\hline 600 & 21.6 & 21.6 & 21.7 & 23.8 & 21.5 \\
\hline C.V. (\%) & 7.05 & 7.24 & 12.43 & 12.41 & 8.62 \\
\hline $\mathrm{F}_{\mathrm{N} \text { fertilizationx Glyphosate doses }}$ & $0.40^{\text {ns }}$ & $0.26^{\text {ns }}$ & $0.54^{\mathrm{ns}}$ & $0.63^{\text {ns }}$ & $1.70^{\text {ns }}$ \\
\hline
\end{tabular}

Means followed by the same letter in the column do not differ by Tukey's test at $\mathrm{p} \leq 0.05$; Equations: ${ }^{(1)} \mathrm{Y}=24.4-0.0049^{* *} \mathrm{X}\left(\mathrm{R}^{2}=0.99\right)$ and ${ }^{(2)} \mathrm{Y}=23.2-0.0028^{* *} \mathrm{X}\left(\mathrm{R}^{2}=0.97\right) ; \mathrm{ns}$ and $^{* *}$ - Not significant and significant at $\mathrm{p} \leq 0.01$ by F test, respectively; $\mathrm{N}$ via leaf: $1 \%$ urea in a $200 \mathrm{~L} \mathrm{ha}^{-1}$ spray, corresponding to $0.09 \mathrm{~g} \mathrm{~m}^{-2} \mathrm{~N}$

$\mathrm{N}$ doses promote more intense green color, desirable from an aesthetic point of view and, physiologically, plants with more intense green color have greater capacity for photosynthesizing carbohydrates due to the higher concentration of chlorophyll, a molecule responsible for capturing the light energy from solar radiation (Godoy et al., 2012a).

Foliar N application was expected to have some effect on lawn color, but it was not observed in the LCI values, since there was no difference in the evaluations between the foliar application of $\mathrm{N}$ or the absence of application (Table 2).

There was a reduction in LCI with increasing doses of glyphosate, in the $1^{\text {st }}$ and $2^{\text {nd }}$ evaluations (Table 2). Therefore, the highest dose of glyphosate ( $600 \mathrm{~g} \mathrm{ha}^{-1}$ of a.i.) was not adequate because it interfered with the aesthetic aspect (green color).

On the other hand, Dinalli et al. (2015) found that the application of glyphosate ( $200 \mathrm{~g} \mathrm{ha}^{-1}$ of a.i.) reduced the growth of Esmeralda grass and did not influence its LCC, maintaining its green color. Gazola et al. (2016) also verified that the application of this herbicide ( $200 \mathrm{~g} \mathrm{ha}^{-1}$ of a.i.) did not reduce the dark green color index of Esmeralda grass.

Su et al. (2009) evaluated the application of glyphosate in nine grass species and verified a negative correlation between visual injury and dry matter production, indicating that the outbreak of injury symptoms, such as chlorosis and necrosis, are associated with the inhibition of biomass production. Thus, although the application of $600 \mathrm{~g} \mathrm{ha}^{-1}$ of glyphosate promotes the lowest growth in height (Figure 2) and, consequently, in shoot dry matter, thus reducing the removal of nutrients by grass cutting, there is an increase of chlorosis in the leaves and, as a result, lower intensity of the green color (Table 2).

This result may be related to the degeneration of chloroplasts, verified by Campbell et al. (1976) in Agropyron repens $24 \mathrm{~h}$ after the application of glyphosate $(560 ; 1120 ; 1680$; 2240 and $4490 \mathrm{~g} \mathrm{ha}^{-1}$ of a.i.) or to the inhibition of chlorophyll formation (Cole et al., 1983), because it has a negative effect on its synthesis (Yamada \& Castro, 2007).

The highest $\mathrm{P}$ accumulations in the leaves of Esmeralda grass were obtained for the grass that received $30 \mathrm{~g} \mathrm{~m}^{-2}$ of N via soil, with and without foliar $\mathrm{N}$ application, in comparison to the control and to the other treatments. There was a reduction of $29.0 \%$ in the quantities of $P$ accumulated by the leaves with the increase of glyphosate doses (Table 3).
There was interaction between $\mathrm{N}$ fertilization and herbicide doses for the accumulation of $\mathrm{N}$ and $\mathrm{K}$ (Table 3 and Figure 3) in the leaves of Esmeralda grass, considering the sum of the five evaluations/cuttings of the grass. Regardless of glyphosate dose and absence/presence of foliar $\mathrm{N}$ application, the largest accumulations of $\mathrm{N}$ and $\mathrm{K}$ were obtained with the highest dose of $\mathrm{N}\left(30 \mathrm{~g} \mathrm{~m}^{-2}\right)$, followed by the dose of $15 \mathrm{~g} \mathrm{~m}^{-2}$ of $\mathrm{N}$, which led to a value higher than that in the control (Figure 3).

There was a linear reduction in the accumulated amount of $\mathrm{N}$ in the leaves of the lawn with the increase in glyphosate doses, when $15 \mathrm{~g} \mathrm{~m}^{-2}$ of $\mathrm{N}$ was applied via soil and without foliar $\mathrm{N}$ application. Under fertilization with $15 \mathrm{~g} \mathrm{~m}^{-2} \mathrm{~N}$ via soil and with foliar $\mathrm{N}$ application and $30 \mathrm{~g} \mathrm{~m}^{-2}$ of $\mathrm{N}$ via soil, without and with foliar $\mathrm{N}$ application, there was a quadratic effect, with the smallest accumulation of $8.9 \mathrm{~g} \mathrm{~m}^{-2}$ of $\mathrm{N}$ with glyphosate dose of $353 \mathrm{~g} \mathrm{ha}^{-1}$ of a.i., of $11.5 \mathrm{~g} \mathrm{~m}^{-2}$ of $\mathrm{N}$ with $535 \mathrm{~g} \mathrm{ha}^{-1}$ of a.i. and $11.6 \mathrm{~g} \mathrm{~m}^{-2}$ of $\mathrm{N}$ with glyphosate dose of $402 \mathrm{~g} \mathrm{ha}^{-1}$ a.i., respectively (Figure $3 \mathrm{~A}$ ).

For $\mathrm{K}$, with $15 \mathrm{~g} \mathrm{~m}^{-2}$ of $\mathrm{N}$ via soil and without foliar $\mathrm{N}$ application and with $30 \mathrm{~g} \mathrm{~m}^{-2}$ of $\mathrm{N}$ via soil, with and without foliar $\mathrm{N}$ application, there was a reduction in foliar accumulation as the glyphosate doses increased. For $15 \mathrm{~g} \mathrm{~m}^{-2}$ of

Table 3. Quantity of N, P and K accumulated by the leaves of Esmeralda grass as a function of nitrogen fertilization, considering the sum of the five evaluations

\begin{tabular}{|c|c|c|c|}
\hline \multirow{2}{*}{ Nitrogen fertilization } & \multicolumn{3}{|c|}{ Quantity accumulated $\left(\mathrm{g} \mathrm{m}^{-2}\right)$} \\
\hline & $\mathbf{N}$ & $\mathbf{P}$ & $\bar{K}$ \\
\hline Control & 5.5 & $2.0 \mathrm{c}$ & 3.2 \\
\hline $15 \mathrm{~g} \mathrm{~m}^{-2}$ of $\mathrm{N}$ and without foliar $\mathrm{N}$ & 9.2 & $2.8 \mathrm{~b}$ & 4.8 \\
\hline $15 \mathrm{~g} \mathrm{~m}^{-2}$ of $\mathrm{N}$ and with foliar $\mathrm{N}$ & 9.9 & $3.0 \mathrm{~b}$ & 5.1 \\
\hline $30 \mathrm{~g} \mathrm{~m}^{-2}$ of $\mathrm{N}$ and without foliar $\mathrm{N}$ & 13.2 & $3.7 \mathrm{a}$ & 6.6 \\
\hline $30 \mathrm{~g} \mathrm{~m}^{-2}$ of $\mathrm{N}$ and with foliar $\mathrm{N}$ & 13.0 & $3.7 \mathrm{a}$ & 6.3 \\
\hline LSD (5\%) & 1.4 & 0.5 & 0.8 \\
\hline \multicolumn{4}{|l|}{ Glyphosate doses ( $\mathrm{g} \mathrm{ha}^{-1}$ of a.i.) } \\
\hline 0 & 12.8 & $3.7^{(1)}$ & 6.6 \\
\hline 200 & 10.0 & 3.0 & 5.2 \\
\hline 400 & 9.1 & 2.6 & 4.7 \\
\hline 600 & 8.8 & 2.7 & 4.3 \\
\hline C.V. (\%) & 11.79 & 14.30 & 12.31 \\
\hline $\mathrm{F}_{\mathrm{N} \text { fertilizationx Glyphosate doses }}$ & $3.19^{* *}$ & $1.78^{\mathrm{ns}}$ & $3.40^{* \star}$ \\
\hline
\end{tabular}

Means followed by the same letter in the column do not differ by Tukey's test at $\mathrm{p} \leq 0.05$ Equation: ${ }^{(1)} \mathrm{Y}=3.51-0.0017^{\star *} \mathrm{X}\left(\mathrm{R}^{2}=0.78\right)$; ns and ${ }^{* *}$ - Not significant and significant at $\mathrm{p} \leq 0.01$ by $\mathrm{F}$ test, respectively; $\mathrm{N}$ via leaf: $1 \%$ urea in a $200 \mathrm{~L} \mathrm{ha}^{-1}$ spray, corresponding to $0.09 \mathrm{~g} \mathrm{~m}^{-2} \mathrm{~N}$ 

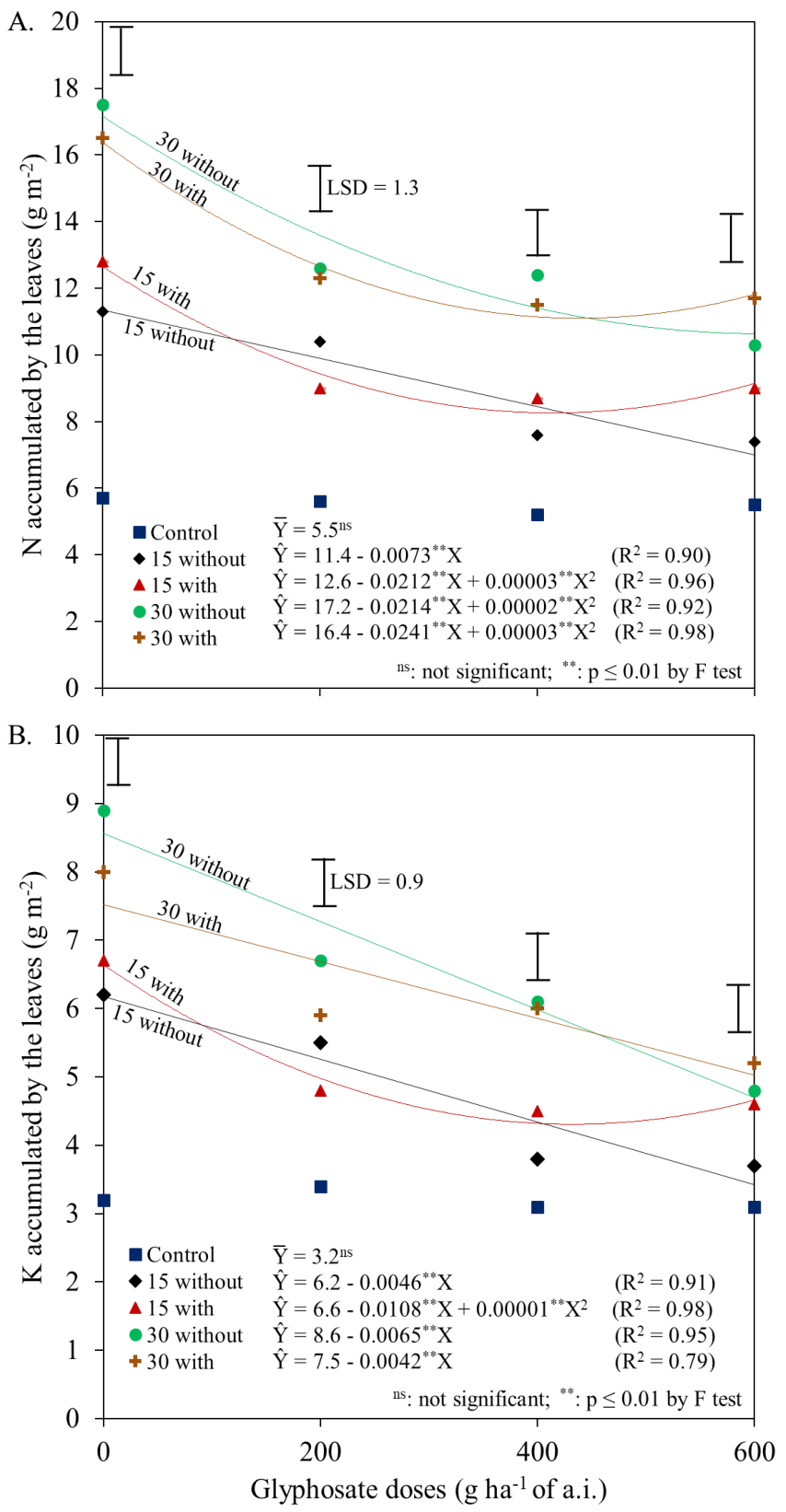

LSD - Least significant difference

Figure 3. Quantities of $\mathrm{N}$ and $\mathrm{K}$ accumulated by the leaves of Esmeralda grass, considering the sum of five evaluations, obtained from the single-effect analysis of the interaction between the application of glyphosate doses and application of $\mathrm{N}$ ( $\mathrm{A}$ and $\mathrm{B}$, respectively)

$\mathrm{N}$ via soil and with foliar $\mathrm{N}$ application, there was a quadratic effect, with the lowest accumulation of $3.7 \mathrm{~g} \mathrm{~m}^{-2}$ of $\mathrm{K}$ at glyphosate dose of $540 \mathrm{~g} \mathrm{ha}^{-1}$ of a.i. (Figure 3B).

At the dose $30 \mathrm{~g} \mathrm{~m}^{-2}$ of $\mathrm{N}$, the application of 535 and $402 \mathrm{~g} \mathrm{ha}^{-1}$ of the a.i. of glyphosate (with and without foliar $\mathrm{N}$ application, respectively) resulted in reductions of 33.1 and $29.3 \%$ of the accumulated N, respectively (Figure 3A). For K, the application of $600 \mathrm{~g} \mathrm{ha}^{-1}$ of glyphosate (with and without foliar $\mathrm{N}$ application, respectively) resulted in reductions of 45.3 and $33.6 \%$ of the accumulated $\mathrm{K}$, respectively.

The smaller accumulated amount of nutrients as a function of glyphosate application is due to the reduction of Esmeralda grass growth caused by the herbicide (Table 1) and, consequently, the reduction in dry matter production.
The effects of glyphosate application as growth regulator have been reported in lawns, such as the reductions of dry matter production in Bahia grass (Barbosa et al., 2017), of $22 \%$ in the height of the Centipede grass (Fry, 1991) and in the height and dry matter of Esmeralda grass (Dinalli et al., 2015). This reduction implies less removal of leaves in the cutting operation and, consequently, less export of nutrients.

The reduction in dry matter production can be explained by the mechanism of action of glyphosate, because its application acts on the route of the shikimic acid, inhibiting the enzyme EPSPs, thus not promoting the synthesis of chorismate (Yamada \& Castro, 2007), besides other compounds derived from this metabolic route, such as vitamins ( $\mathrm{K}$ and $\mathrm{E}$ ), hormones (auxin, ethylene), alkaloids and several other secondary products (Kruse et al., 2000), for example, phenolic compounds, which can correspond to $35 \%$ of plant biomass (Boudet et al., 1985).

It is worth pointing out that the increase in the accumulated amount of $\mathrm{N}, \mathrm{P}$ and $\mathrm{K}$ in the lawn leaves results in a greater need for replenishment through fertilization, because the leaves are removed in the cutting operation. Therefore, the highest $\mathrm{N}$ dose was not adequate. In addition, the minimum accumulated quantities were generally promoted under application of glyphosate doses between 400 and $600 \mathrm{~g} \mathrm{ha}^{-1}$ of a.i. (Table 3 and Figure 3), which is interesting, because there would be lower costs with cutting and also reduction in the need for replenishing the exported nutrient, through fertilization.

Based on the results obtained, $\mathrm{N}$ was the most accumulated nutrient in the leaves of Esmeralda grass, followed by $\mathrm{K}$ and $\mathrm{P}$, regardless of $\mathrm{N}$ fertilization and application of glyphosate doses (Table 3).

\section{Conclusions}

1. Fertilization with $15 \mathrm{~g} \mathrm{~m}^{-2}$ of $\mathrm{N}$ via soil and without foliar $\mathrm{N}$ application, split into five times a year, promoted adequate visual quality, based on leaf chlorophyll index.

2. Complementary application of $\mathrm{N}$ through the leaves was unnecessary.

3. Glyphosate at dose of $400 \mathrm{~g} \mathrm{ha}^{-1}$ of a.i. was efficient in reducing the growth of Esmeralda grass, and did not hamper its color and led to less accumulation of N, P and K by the leaves.

\section{ACKNOWLedgments}

To Fundação de Amparo à Pesquisa do Estado de São Paulo (FAPESP) for research funding (Process number 14/02449-8) and $\mathrm{CNPq}$ (Conselho Nacional de Desenvolvimento Científico e Tecnológico) by productivity grants in research (Process number 305.299/2014-0 and 312359/2017-9) for the financial support.

\section{Literature Cited}

Backes, C.; Lima, C. P.; Godoy, L. J. G.; Santos, A. J. M.; Villas Bôas, R. L.; Büll, L. T. Produção, acúmulo e exportação de nutrientes em grama esmeralda adubada com lodo de esgoto. Bragantia, v.69, p.413-422, 2010. https://doi.org/10.1590/S000687052010000200021 
Barbosa, A. P.; Meschede, D. K.; Alves, G. A. C.; Freiria, G. H.; Furlan, F. F.; Alves, L. A. R.; Junco, M. C. Paspalum notatum growth and pigment content in response to the application of herbicides. Revista Brasileira de Herbicidas, v.16, p.142-151, 2017. https:// doi.org/10.7824/rbh.v16i2.520

Boudet, A. M.; Graziana, A.; Ranjeva, R. I. Recent advances in the regulation of the prearomatic pathway. In: Sumere, C. F. van; Lea, P. J. The biochemistry of plant phenolics. Oxford: Claredon Press, 1985. p.135-159.

Campbell, W. F.; Evans, J. O.; Reed, F. C. Effect of glyphosate on chloroplast ultrastructure of quackgrass mesophyll cell. Weed Science, v.24, p.22-25, 1976. https://doi.org/10.1017/ S0043174500065346

Christoffoleti, P. J.; Aranda, N. A. Seletividade de herbicidas a cinco tipos de gramas. Planta Daninha, v.19, p.273-278, 2001. https:// doi.org/10.1590/S0100-83582001000200016

Cole, D. J.; Caseley, J. C.; Dodge, A. D. Influence of glyphosate on selected plant process. Weed Research, v.23, p.173-183, 1983. https://doi.org/10.1111/j.1365-3180.1983.tb00535.x

Dinalli, R. P.; Buzetti, S.; Gazola, R. N.; Castilho, R. M. M.; Celestrino, T. S.; Dupas, E.; Teixeira Filho, M. C. M.; Lima, R. C. Doses de nitrogênio e aplicação de herbicidas como reguladores de crescimento em grama esmeralda. Semina: Ciências Agrárias, v.36, p.1875-1894, 2015.

Duke, S. O.; Hoagland, R. E.; Elmore, D. Effects of glyphosate on metabolism of phenolic compounds. Plant Physiology, v.65, p.1721, 1980. https://doi.org/10.1104/pp.65.1.17

Ferreira, D. F. Sisvar: A computer statistical analysis system. Ciência e Agrotecnologia, v.35, p.1039-1042, 2011. https://doi.org/10.1590/ S1413-70542011000600001

Fry, D. J. Centipedegrass response to plant growth regulators. HortScience, v.26, p.40-42, 1991. https://doi.org/10.21273/ HORTSCI.26.1.40

Gazola, R. P. D.; Buzetti, S.; Gazola, R. N.; Castilho, R. M. M.; Teixeira Filho, M. C. M.; Celestrino, T. S.; Dupas, E. Nitrogen dose and type of herbicide used for growth regulation on the green coloration intensity of Emerald grass. Ciência Rural, v.46, p.984-990, 2016. https://doi.org/10.1590/0103-8478cr20150276

Gitti, D. C.; Arf, O.; Peron, I. B. G.; Portugal, J. R.; Corsini, D. C. D. C.; Rodrigues, R. A. F. Glyphosate como regulador de crescimento em arroz de terras altas. Pesquisa Agropecuária Tropical, v.41, p.500-507, 2011. https://doi.org/10.5216/pat.v41i4.10160

Godoy, L. J. G.; Backes, C.; Villas Bôas, R. L.; Santos, A. J. M. Nutrição, adubação e calagem para produção de gramas. 1.ed. Botucatu: FEPAF, 2012a. 146p.

Godoy, L. J. G.; Villas Bôas, R. L.; Backes, C. Produção de tapetes de grama Santo Agostinho submetida a doses de nitrogênio. Semina: Ciências Agrárias, v.33, p.1703-1716, 2012b. https://doi. org/10.5433/1679-0359.2012v33n5p1703
Johnson, B. J. Influence of plant growth regulators and mowing on two bermudasgrasses. Agronomy Journal, v.6, p.805-810, 1994. https://doi.org/10.2134/agronj1994.00021962008600050011x

Kaufmann, J. E. Winning with turfgrass growth regulators. ALA Technology, v.6, p.31-39, 1985.

Kruse, N. D.; Michelangelo, M. T.; Vidal, A. V. Herbicidas inibidores da EPSPs: Revisão de literatura. Revista Brasileira de Herbicidas, v.1, p.139-146, 2000. https://doi.org/10.7824/rbh.vli2.328

Leite, G. H. P.; Crusciol, C. A. C. Reguladores vegetais no desenvolvimento e produtividade da cana-de-açúcar. Pesquisa Agropecuária Brasileira, v.43, p.995-1001, 2008. https://doi. org/10.1590/S0100-204X2008000800007

Lima, C. P.; Backes, C.; Santos, A. J. M.; Fernandes, D. M.; Villas Bôas, R. L.; Oliveira, M. R. Quantidade de nutrientes extraídos pela grama bermuda em função de doses de nitrogênio. Bioscience Journal, v.31, p.1432-1440, 2015. https://doi.org/10.14393/BJv31n5a2015-21967

Malavolta, E.; Vitti, C. G.; Oliveira, A. S. Avaliação do estado nutricional das plantas: Princípios e aplicações. 2.ed. Piracicaba: Potafós, 1997.317p.

March, S. R.; Martins, D.; McElroy, J. S. Growth inhibitors in turfgrass. Planta Daninha, v.31, p.733-747, 2013. https://doi.org/10.1590/ S0100-83582013000300025

Meschede, D. K.; Velini, E. D.; Carbonari, C. A. Efeitos do glyphosate e sulfometuron methyl no crescimento e na qualidade tecnológica da cana-de-açúcar. Planta Daninha, v.28, p.1135-1141, 2010. https://doi.org/10.1590/S0100-83582010000500021

Raij, B. van.; Andrade, J. C.; Cantarella, H.; Quaggio, J. A. Análise química para avaliação da fertilidade de solos tropicais. Campinas: Instituto Agronômico de Campinas, 2001. 285p.

Silva, D. F. Análises quantitativa e qualitativa do crescimento e desenvolvimento da grama-batatais e grama-esmeralda em diferentes lâminas de irrigação. Viçosa: UFV, 2004. 62p. Dissertação Mestrado

Silva, M. A.; Aragão, N. C.; Barbosa, M. A.; Jeronimo, E. M.; Carlin, S. D. Efeito hormótico de gliphosate no desenvolvimento inicial de cana-de-açúcar. Bragantia, v.68, p.973-978, 2009. https://doi. org/10.1590/S0006-87052009000400017

Su, Y. S.; Ozturk, L.; Cakmak, I.; Budak, H. Turfgrass species response exposed to increasing doses of glyphosate application. European Journal of Agronomy, v.31, p.120-125, 2009. https:// doi.org/10.1016/j.eja.2009.05.011

Velini, E. D.; Duke, S. O.; Trindade, M. L. B.; Meschede, D. K.; Carbonari, C. A. Modo de ação do glyphosate. In: Velini, E. D.; Meschede, D. K.; Carbonari, C. A.; Trindade, M. L. B. Glyphosate. Botucatu: FEPAF, 2009. Cap.5, p.113-133.

Yamada, T.; Castro, P. R. C. Efeito do glifosato nas plantas: Implicações fisiológicas e agronômicas. Piracicaba: International Plant Nutrition Institute/ Brazil, 2007. 32p. Encarte Técnico Informações Agronômicas, 119 